\title{
ПОВЕЗАНОСТ АКТУЕЛНОГ СТАТУСА СРПСКОГ ЈЕЗИКА У БОСНИ И ХЕРЦЕГОВИНИ И ДЕКЛАРАЦИЈЕ О ЗАЈЕДНИЧКОМ ЈЕЗИКУ
}

У раду се говори о актуелном социолингвистичком статусу српског језика у Босни и Херцеговини, на који неповољно утиче недовољна брига српских инстутуција о језику као основном идентитетском критеријуму, немаран однос корисника језика у употреби, као и антисрпски филолошки програми који теже брисању српског имена језика у босанскохерцеговачком културном простору. Међу њима је посебно агресивно настојање бошњачких филолога и политичара да разним квазикритеријумима асимилују све који живе у Босни и Херцеговини у оквиру босанског језичког и националног идентитета. Наглашава се неопходност не само научне и васпитно-образовне него и институционалне заштите српског језика и промовисања ћирилице да би се на босанскохерцеговачком подручју сачувао српски национални корпус и његова култура.

Кључне ријечи: српски језик, норма, стандардизација, функционална писменост, декларација

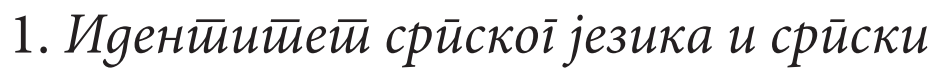
национални ияентиитетеи у Босни и Херцеїовини

Статус српског језика у Босни и Херцеговини, у првим деценијама 21. вијека, мора се посматрати на два плана 
- на функционалном и на друштвено-политичком. И на једном и на другом - неопходно га је посматрати у оквирима и Републике Српске и Босне и Херцеговине, при чему треба имати на уму да на његов статус у државним границама значајно утиче и његов статус у другом ентитету - у Федерацији БиХ. Фактички се у контексту ван граница Републике Српске под статусом српског језика подразумијева однос његовог изворног имена и етнички мотивисаних преименица, а у оквиру Републике Српске, осим тога, и његово мјесто у развојним плановима просвјетних и научних институција и ниво функционалне писмености његових корисника.

Што се статуса српског језика у Републици Српској тиче - било да се говори о институционалном било о функционалном - поставља се питање да ли је чување и његовање српског језика брига само неколицине лингвиста, односно србиста или је национални интерес. Ако је национални интерес, онда мора тај интерес да заступа и Скупштина РС у програмима свога рада и рада својих одбора, Влада РС - посебно министарства просвјете и науке, Академија наука и умјетности РC, а онда да се то преноси на ниже нивое - на универзитете и јавне и приватне - на комплетан школски систем, на све институције од јавног значаја. Све наше институције до сада су давале предност материјалној култури, неопходости повезивања науке и привреде, што је свакако врло важан и потребан циљ, не посвећујући или посвећујући маргинално пажњу питању језика и његовог статуса у друштвено-политичким приликама БиХ. У поменутим министарствима однос према националним дисциплинама зависи од свијести министра, па се мора рећи да је у новије вријеме (у периоду од 2013. до 2017. године) у Министарству просвјете јасније артикулисан став да је проблем српског језика проблем националне природе, али и ту се изњедрио у сврху крајње одбране - када је 
босанско име језика закуцало директно на врата Министарства кроз захтјеве да се у школском систему употребљава равноправно са изворним српским. Тај став о виталности српског језика као о суштинском националном интересу јасно заступа предсједник РС, што му се у босанскохерцеговачком окружењу замјера. У суштини, институционална брига о језику је оскудна и несистематична - колико се мора и кад се баш мора, што показује и Стратегија научног технолошког развоја Републике Српске, именована као „Знање за развој,„, коју је за период од 1917. до 1921. израдило Министарство за науку и технолошки развој, у коме је стратегија развоја националних и уопште хуманистичких наука маргинализована у односу на друге за које се сматра да су у основи профитабилности и економског развоја друштва, што је ваљда у складу са мотом плана, прокламованим и у самом називу документа. Као члан Савјета за науку, реаговала сам док је тај документ био у фази израде, поводом суштинског недостатка да развоју наука које су у основи културе једног друштва није посвећено скоро нимало пажње, али нисам успјела да тиме значајније утичем на промјену финалне верзије Стратегије. Поставља се питање да ли је за Владу Републике Српске уопште битна стратегија развоја и промовисања националних дисциплина у које као примарне спадају национални језик, књижевност и историја. Зашто Одјељење за језик, које постоји при Академији наука и умјетности Републике Српске, активније не ради на промовисању не само описа садашњег хаотичног стања у именовању и нормирању српског језика у БиХ него и неопходном објашњавању јавности историјских чињеница које се односе на српске писане споменике из најранијих периода писмености са тла садашње Босне и Херцеговине, а који су предмет отимања од стране Хрвата и Бошњака, који и кроз историју писмености желе да успоставе несрпски континуитет језика и културе босан- 
скохерцеговачке регије. У друштву поремећеног система вриједности, у времену које духом својим потире национално у свјетски глобалистичком, народна изрека „или не умио - или немао, сасвим одговара стању свијести Срба као друштва у држави Босни и Херцеговини. Зато што не умијемо да с врха најзначајнијих институција бранимо и промовишемо своје културне тековине, што не знамо да их приближимо чак ни образованом човјеку, помажемо фалсификаторима историје да Повельу Кулина $\delta a н a$, најстарију датирану (29. август 1189) српску ћириличну повељу писану народним језиком, проглашавају несрпском, чиме настоје да негирају постојање Срба у 12. вијеку на подручју садашње Босне и Херцеговине.

А удосезањуциљева који воде ка поништавању српског идентитета у Босни и Херцеговини представници институција других народа не бирају нити провјеравају „аргументе,, него их обликују у складу са циљем. Тако поводом Међународног дана матерњег језика (21. фебруар), на трибини о језику одржаној 2016. године у Академији наука и умјетности БиХ, предсједник Бошњачке академије наука и умјетности (основане 2011. године у Новом Пазару) академик Мухамед Филиповић изјављује да је „u Bosni i Hercegovini prisutan drastičan slučaj da se ospori postojanje maternjeg jezika i njegovog imena bosanski jezik iako je on najtrajniji i najviše dokumentiran jezik,, те да „ukoliko danas čitate neke historijske dokumente ili natpise na stećcima, moći ćete razumjeti šta tamo piše, što nije slučaj sa drugim jezicima jer je staroslavenski i crkvenoslavenski sasvim drugo od bosanskog, ( https;//www.hajat.ba, 22. 2. 2016). Мухамед Филиповић потпуно изједначава појам матерњег језика у Босни и Херцеговини са називом босански језик. Простор његовог матерњег језика је простор цијеле Босне и Херцеговине, па он изражава и невјерицу да неко ко ту живи и говори негира име свога матерњег језика који се, према његовом мишљењу, може звати искључиво „босан- 
ски,. С друге стране, у традицији српске писмености на босанскохерцеговачком простору Филиповић искључује писменост на народном језику, везујући је искључиво за старословенски и/или црквенословенски језик. Тиме жели да представи да је Повеља Кулина бана још у 12. вијеку била писана „босанским језиком, (коме је неко забрањивао да се тако зове све до краја 20. вијека, па и сада), а да су једино црквени списи црквенословенског књижевног језика, пошто ваљда припадају хришћанству, а не исламу, споменици српске традиције. Тај модел преправљања историје српског књижевног језика као језика који је Вук пренио из Босне у Србију, а преко ње је наметнут и у бившој Југославији, представља најновији тренд до кога је дошла „боснистика, у покушајима да прибави историјску подлогу босанском имену језика старију од краја 20. вијека. Настојећи да књижевни српски језик у Босни и Херцеговини прогласи регионалном варијантом „страног центра,, „увезеном, из Србије, бошњачки лингвиста Сенахид Халиловић пропагира за подручје БиХ „опћебосански стандард,:

„Zato bi najprimjereniji bio općebosanski standard, široko zasnovan, koji bi obuhvatao cjelokupnu bosanskohercegovačku jezičku stvarnost. Bosanski standard različitim od hrvatskog i srpskog ne čine samo njegova bošnjačka dionica i ona koja se ne da podvesti pod nacionalne sheme, nego i druge dvije, koje se uvjetno mogu označiti kao hrvatski bosanski i srpski bosanski. Naime, jezik Hrvata odnosno Srba u BiH, i kad se doživljava i naziva hrvatski odnosno srpski, nije isto što i hrvatski u Hrvatskoj ili srpski u Srbiji, (Халиловић 2014: 257-258).

Халиловићево тумачење стандардног језика у Босни и Херцеговини као аутентично „босанског,, а језичких израза Срба и Хрвата као србијанске и хрватске „језичке 
дијаспоре,, подударно је са настојањима Џевада Јахића да Србе и Хрвате прогласи језичким странцима у БиХ. Јахић сматра да се „previđa jedna bitna razlika između književnojezičkog izraza bh. Srba i Hrvata, s jedne strane, i Bošnjaka, s druge strane. Naime, bh. Srbi i Hrvati imaju svoje nacionalne i jezičke matice van Bosne i Hercegovine, dok ih bošnjaci nemaju», (Јахић и други 2004: 62).

И једно и друго мишљење одређују бошњачку књижевнојезичку политику као политику језичке националне асимилације Срба и Хрвата у оквиру босанског

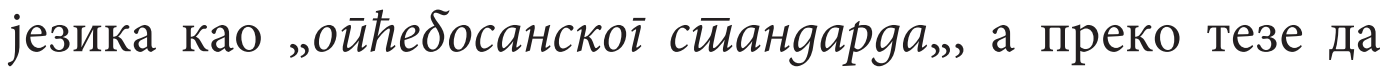
су босанскохерцеговачки Срби (и Хрвати) прихватили за свој језик и језички стандард „страних центара,, али будући да га употребљавају у оквирима „босанског језика,, он се од тих матичних стандарда разликује по „босанским, нијансама. А „босанске нијансе, сматрају се идентитетским, јер се у оквиру њих идентитети других језика неутралишу! Ови и бројни други примјери показују да смо окружени онима са којима дијелимо заједничко културно насљеђе српског језика, а којима је оно битно до те мјере да га преименују у новоизмишљени не само национални него и шире од тога - у други културно-језички идентитет, па је зато питање статуса српског језика у Босни и Херцеговини суштинско питање српских националних институција. Заступам мишење да је култура српског језика много шира од културе Срба, јер она нужно обухвата и стваралаштво других народа на српском језику - Хрвата, Бошњака, оних који се осјећају Црногорцима, као и других националних мањина.

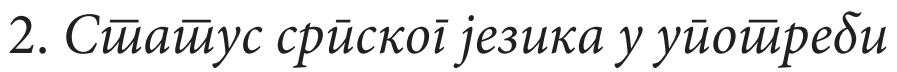

Функционално је у употреби језик сасвим запуштен - језичка култура већине корисника језика у РС одра- 
жава некултивисаност и ћаскашки опуштен стил изражавања, који надире под утицајем интернет-комуникације. Најгоре је што схватање језика као алатке у комуникацији постаје општеприхваћено, па они који на то указују као на негативну појаву, који сматрају да би не само сваки медиј него и свака институција требало да има лектора, да смо обавезни придржавати се језичке норме, постају смијешни у очима већине. Шта се све може чути, какве језичке вулгарности у политичком дискурсу (посебно у Скупштини РС или у тзв. Парламентарној или „Скупштинској“ скупштини БиХ), какво незнање српског језика и ћирилице доносе на факултет свршени средњошколци, а најгоре је што и одлазе с њим и улазе у живот друштва. Зато сматрам неопходним као сламку спаса - да се српски језик уведе као обавезни општи предмет на све факултете, да би се поправила елементарна писменост академских грађана. Недавно ми је студент англистике на испиту из Српског језика рекао да је свјестан да не зна српски. Када сам га питала за разлог, јер је добар студент, рекао ми је да му је непријатно да то каже преда мном, али да му је учење српског језика одувијек било глупо јер зна да се њиме служи. Такву слику - у којој је служење језиком својствено и неписменима, а у којој образовани нису свјесни да је познавање језичке норме и његовање језичке културе својствено друштвеној елити, дужни смо да мијењамо и као појединци и као представници образовног система, али не можемо без озбиљнијих стандарда, односно без подизања статуса српског језика на ниво језика значајног макар колико и енглески - будући да нам је скоро сва комуникација на српском.

У Федерацији БиХ само формално се наводи српско име језика, у складу са прокламованим принципом о равноправности народа и језика, и то не у свим кантонима, а суштински српског стандарда скоро да и нема. Једина 
битнија разликовна црта у употреби оног стандарда српског језика који Бошњаци зову босанским, а Хрвати хрватским - јесте секундарност ћирилице у односу на стандард код Срба, па тако скоро ниједно дијете које основну школу заврши у Федерацији и уписује се у срдењу школу у Источном Сарејеву не зна да чита и пише ћирилицу. Српски стандард, дакле, ни када је у питању писмо, ни друге нијансе у Федерацији нико не учи. На филолошким и педагошким факултетима студијски програм се назива Босански, хрватски и српски језик и књижевност, па студенти на основу два-три испита из књижевности писаца Срба и норме српског језика добијају привид у дипломи да су оспособљени да предају три језика и три књижевности. На тај начин бошњачки лингвистички идеолози пројектују босански језик као први од три језика на простору Федерације, а фактички као једини, јер је од српског узео све осим имена, а од стандарднојезичке западне или хрватске варијанте нешто кроатизама, од којих је српском системски страно мало шта, као нпр. грађење сложеног

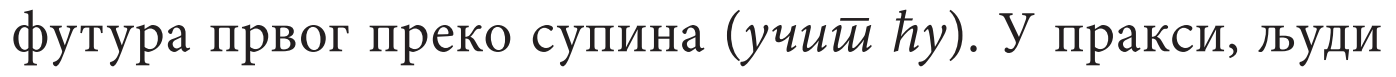
говоре како говоре, мало ко зна да употребљава накалемљене кроатизме, говоре и даље српским, па је та тројезичка смијурија најдосљеднија у тзв. заједничким органима, у већ поменутој Парламентарној скупштини и другим тијелима, гдје се сваки час преводи, зарад чега је измишљено и радно мјесто лектор-преводилац који се довија како да српски што мање личи на српски. Инсистирање на босанском имену за специфичности употребе српског језика код Бошњака, на глотониму ширем од имена народа, води само ка једном циљу пројектовању тог имена у име државног језика Босне и Херцеговине. Кратковиди су Срби који то не виде и који мисле да их то у будућности не угрожава. 
3. „Декларачија о зајеgничком језику, йротиив срйскоі језика и юеі̄ове йраgиције

Шлаг на ту социолингвистичку торту у културној и политичкој јавности српског говорног подручја крајем марта ове године умутила је Декларација о зајеgничком језику (в. Бабић 2016) ${ }^{1}$, којом су представљени резултати пројекта Језиии и национализми, који су током 2016. и с почетка 2017. године реализовале четири невладине организације: ПЕН ценйар из Сарајева, Курс из Сплита, Крокоgил из Београда и Ценйар за ірађанско образоване из Подгорице, с циљем да се коначно неким документом који би требало да буде општеприхваћен запечати свођење Вуков(ск)ог српског језика на једну од варијаната и његово четвороименовање. Асоцијативно врло тенденциозно успоставивши везу са педесетогодишњом традицијом претходеће јој имењакиње, нова декларација настоји да овјери модел измишљен 1967. године Деклараиијом о називу и йоложају хрвайскоі книжевног̄ језика, према којем сваки народ добија до тада непостојеће, а ни отада нигдје друго него у ексјугословенском простору примјењивано право да свој језик именује сопственим именом, без обзира на генезу, историју и традицију језика којим се служи. Циљ нове декларације-реплике јесте да тим начелом обухвати комплетан простор српског језика и да га и вољом грађана-потписника распарча. У пренаглашеној медијској промоцији представљена је као некав измишљени компромис на напрегнутој економско-политичкој и културној матрици истојезичких република и нација бивше СФРЈ, а у ствари у њој се мућкају познате чињенице, од којих многе, патетично представљене као иновације умних „експерата,, одавно

1 Дио текста који се односи на Декларацију о зајеgничком језику објављен је у раду М. Бабић (2017: 127-130). 
нико и не доводи у питање. Тако је информативна новост да је потврдан одговор „на питање да ли се у Босни и Херцеговини, Црној Гори, Хрватској и Србији употребљава заједнички језик, „2 на нивоу „откривања топле воде,, па би било бесмислено додавати јој још и неки општепознати коментар. Колико је ненаучно или колико је нелогично утемељен захтјев за слободним именовањем језика, показује једно од суштинских образложења које гласи: „Ријеч је о заједничком стандардном језику полицентричног типа - односно о језику којим говори више народа у више држава с препознатљивим варијантама - какви су њемачки, енглески, арапски, француски, шпањолски, португалски и многи други,. Најприје је нелогично што „експерти, не наводе који је то језик, а навели су аналогне њемачки, енглески, арапски итд. Могли су поштено рећи да је процес стандардизације заједничког језика започео са Вуковим српским те да се управо тај заједнички језик као база варијантама одржао кроз два вијека и заједничке и дисолуцијске стандардизације у оквиру нација које њиме говоре. Друга нелогичност јесте у томе што је поређење са наведеним варијантним или полицентричним језицима тобоже извршено по једнакости, а у ствари по неједнакости, јер ниједан од наведених језика није преименован према национално-територијалној распрострањености, па чак ни америчка варијанта енглеског као језика најмоћније (уз Русију!) свјетске силе није добила посебно америчко име.

Прокламујући анационалну „широкогрудост, Декларација промовише некакав повампирени језик без историје, с циљем демотивације његовог имена - он се као никако не зове или се зове како ко индивидуално хоће, па

2 Сви цитати текста Декларације преузети су у полухрватској верзији са сљедеће адресе: https://sh.wikipedia.org/wiki/ Deklaracija_o_zajedničkom_jeziku, 9. 5. 2017. 
ако неко хоће и српским да га зове - нека га зове, неће се нико љутити, јер то име представља по Декларацији само једну од варијаната. А однос међу варијанатама је такав да: „све четири тренутно постојеће стандардне варијанте равноправне су и не може се једна варијанта сматрати језиком, а друге варијантама заједничког језика,. Тиме се контрадикторно тврди да заједнички језик постоји, али да не постоји, јер постоје само његове равноправне варијанте! Очито „експерти, желе да пониште статус српског књижевног језика, чије су варијанте (пре)именоване од 19. до 21. вијека различитим именима, јер га они свођењем на варијанту проглашавају непостојећим. И то је, очито, суштинска намјера Декларације да „под фирмом, великодушног „експертског, компромиса у рјешавању проблема у језичком заједништву - које су још са Декларацијом из 1967. и званично напустили Хрвати, с посљедњим грађанским ратом и Бошњаци и ултранационалистички оријентисани Црногорци - омогући да се позивањем на некакве регионалне принципе стандардизације језика и индивидуална права говорника озваниче босански и ирноїорски као државни називи језика у БиХ и у Црној Гори. Прва декларација је, дакле, из српског издвојила хрватски, а ова друга има задатак да потврди и овјери плебисцитарно, потписима великог броја грађана, босански и ирноіорски. Да би се одупро свим тим вишевјековним, а ево и у најновије вријеме актуелним деструктивним тенденцијама, српски мора да сачува своју изражајну надмоћ надваријантног језика у коме се непуристичком језичком политиком - на којој је инсистирао познати српски лингвиста Павле Ивић - чувају у већини и јединице које заговорници посебних стандардних језика настоје прогласити несрпским. А то што језик сам чува у своме историјском континуитету и могућностима у савременој употреби, они којима даје идентитет не би смјели потписом на потписа недостојном тексту, 
какав јесте Декларација о зајеgничком језику, олако да разбацују.

\section{4. Зактьучак}

Сплет друштвено-политичких прилика који прати развој књижевног српског језика, у историјском контексту (два свјетска и једног грађанског рата) у којем су се Срби стално борили за слободу и самосталност, условио је да је манифестација и једног и другог циља у мирнодопским условима стално оспоравана, са драстичном посљедицом да се српски народ из једне - на крају обрео у четири различите државе, што је проблематизовало и статус народа и статус језика и писма као његових највећих тековина и основног кохезивног фактора. Српском језику у БиХ посебну пријетњу представља све отвореније промовисање државног „босанског, језика или - како га називају бошњачки лингвисти - „опћебосанског стандарда,, у оквиру кога се као некаква нова варијанта настоји издвојити „српски босански, којим говоре Срби у БиХ, а који је „различит, од српског у Србији. Та настојања заснована су на критеријуму варијантне полицентричности српског језика, на издвајању тзв. западне или хрватске варијанте (у периоду српскохрватске номинације језика) у односу на матични вуковски српски језик и воде ка проглашавању регионалних нијанси стандарднојезичким варијантама - босанско(херцеговачко)м и црногорском, а преко варијанти и преименованим језицима са државним статусом. Најновији прилог томе процесу представља „Декларација о заједничком језику,, недавно донесена (од стране невладиних организација из Сарајева, Сплита, Београда и Подгорице) - с циљем да се коначно неким документом који би требало да буде општеприхваћен запечати свођење српског језика на једну од четирију варијанти и озваничи 
и на тај начин његово четвороименовање, а посебно да се доврши процес његове „боснизације, и „црногоризације,, што подразумијева и незаобилазно асимиловање Срба у оквиру тих измишљених културних идентитета.

\section{Литература:}

Бабић 2017: М. Бабић, Чему нас учи „Декларација о заједничком језику, народа, „регионалаца, и појединаца, Нова Зора, часопис за књижевност и културу, бр. 53/54, БилећаГацко: Српско просвјетно и културно друштво «Просвјета», 127-130.

Јахић и други 2004: Dževad Jahića, S. Halilovića i I. Palića, Gramatika bosanskoga jezika za srednje škole, Zenica: Dom štampe.

Халиловић 2014: Senahid Halilović, „Jezička stvarnost u Bosni i Hercegovini,,, Radovi, knj. XVII, Sarajevo: Filozofski fakultet u Sarajevu, 243-260.

Доступно он-лајн:

https://sh.wikipedia.org/wiki/Deklaracija_o_zajedničkom_ jeziku, приступљено 9. 5. 2017.. https;//www.hajat.ba, 22. 2. 2016: U posljednjih nekoliko desetljeća nestalo je više od 500 jezika, https;//www.hajat.ba, 22. 2. 2016, приступљено 24. априла 2017. 
Milanka J. Babić

University of East Sarajevo, Pale

Faculty of Philosophy

\section{THE CONNECTION BETWEEN THE ACTUAL STATUS OF THE SERBIAN LANGUAGE IN BOSNIA AND HERZEGOVINA AND THE DECLARATION ON THE COMMON LANGUAGE}

\section{Summary}

Sociopolitical circumstances within which the Serbian language has developed (two world and one civil war), as well as the historical context in which Serbs have always fought for their freedom and independence, resulted in the fact that the manifestation of both of these aspirations have been curbed and denied in the state of peace, with the drastic consequence of Serbs finding themselves living in four different states instead of one, which was the case previously, and which problematized the question of their national status and the status of their language as the greatest national heritage and cohesive factor. Open promotion of "the Bosnian language" or "the general Bosnian standard", as it is called by Bosniak linguists poses the biggest threat to the status of the Serbian language in $\mathrm{B} \& \mathrm{H}$, since it attempts to single out „Serb Bosnian“ as a new language variety which is spoken by Serbs in B\&H and which is "different" from the Serbian language as it is spoken in Serbia. Such attempts are based on the criterion of polycentric variation of the Serbian language, on the differentiation between the so-called western or Croatian variety (during the period of the Serbo-Croatian linguistic nominalization) with respect to Vuk Karadzic'sprincipal variety of the Serbian language and which leads to the proclamation of the regional varieties into the standard ones - such as Bosnian (and Herzegovinian), Montenegrin, and ultimately via these to their 
proclamation into states' languages. The latest contribution to this process is The Declaration on the Common Language that has been recently issued ( by a few non-governmental organizations from Sarajevo, Split, Belgrade and Podgorica) with the aim to narrow down the existence of the Serbian language to one of the four varieties and in this way to make its four-way renaming public and official and in this way to round up the process of its „bosnianization" and "montenegrinization“ which presupposes the inevitable assimilation of the Serbs into these invented and artificial cultural identities.

Key words: Serbian language, norm, standardization, functional literacy, declaration 